\title{
Het effect van de vermogensstructuur op resultaatsturing door middel van reële activiteiten
}

Irina Zagers-Mamedova

\begin{abstract}
SAMENVATTING Recent zorgen de wereldwijde crisis en de krapper geworden kapitaalmarkt voor toenemende terughoudendheid in het verstrekken van leningen aan ondernemingen. Bij de beoordeling van het al dan niet verstrekken van een lening is de verwachte kasstroom uit operationele activiteiten een belangrijke maatstaf. Daarom kunnen ondernemingen een motief hebben om de operationele kasstroom over een bepaalde periode te beïnvloeden. Resultaten kunnen worden beïnvloed door de administratieve verwerking hiervan en door reële activiteiten; kasstromen kunnen echter vrijwel alleen beïnvloed worden door reële activiteiten: het uitstellen of juist versneld uitvoeren van bepaalde activiteiten. In dit artikel ga ik na of verminderde solvabiliteit geassocieerd is met beïnvloeding van operationele kasstromen ('real earnings management') en daarmee een mogelijk motief is voor het verhogen van deze kasstromen. De resultaten hiervan lijken erop te duiden dat bij ondernemingen met een verslechterende solvabiliteit een verhoogd niveau van manipulatie van economische activiteiten wordt waargenomen met als mogelijk doel invloed uit te oefenen op kasstromen uit operationele activiteiten.
\end{abstract}

\section{RELEVANTIE VOOR DE PRAKTIJK Dit artikel toont aan dat manipulatie van economische activiteiten optreedt met als mogelijk doel invloed uit te oefenen op kasstromen uit operationele activiteiten in situaties waarin ondernemingen worden geconfronteerd met verminderde solvabiliteit.}

\section{Inleiding}

Als gevolg van diverse financiële rapporteringschandalen richten analisten en beleggers zich in toenemende mate op de kasstromen van een onderneming, naast de gerapporteerde winsten waar men zich traditioneel op richt. Dit wordt mede veroorzaakt door de hoge rentelasten waarmee steeds meer ondernemingen worden geconfronteerd. In de voorbije jaren hebben zich bijvoorbeeld veel fusies en overnames voltrokken waarbij financiering voor een groot deel door middel van vreemd vermogen werd bewerkstelligd met hogere rentelasten tot gevolg. Naar verwachting zal de wereldwijde economische crisis en de krapper geworden kapitaalmarkt de aandacht voor kasstromen verder verhogen. Voldoende kasstromen uit operationele activiteiten zijn van essentieel belang voor deze ondernemingen om in de toekomst winstgevend en rendabel te blijven.

De betrouwbaarheid van gerapporteerde winstcijfers wordt steeds vaker in twijfel getrokken en ondanks dat sommige studies ervan uitgaan dat kasstromen vrij zijn van beïnvloeding, zijn er in toenemende mate aanwijzingen dat managers daadwerkelijk acties ondernemen met het doel positieve of verbeterde kasstromen uit operationele activiteiten te rapporteren. Deze beïnvloeding kan vrijwel alleen bewerkstelligd worden door middel van manipulatie van werkelijke economische activiteiten (real earnings management) en in mindere mate door middel van manipulatie van overlopende posten (accruals earnings management).

In gedachten houdende dat beleggers en analisten het kasstroomoverzicht in hun beslissingprocessen gebruiken, kunnen gemotiveerde en intelligente managementteams real earnings management hanteren om het ware beeld van kasstromen uit operationele activiteiten te beïnvloeden en daarmee financiële leningen te ontvangen of te behouden. Men vreest dat deze 'opportunistische' beïnvloeding in het bijzonder kan optreden bij ondernemingen met een hoge of toenemende leverage (dat wil zeggen lage of verminderende solvabiliteit), aangezien beleggers en analisten dan goed letten op kasstromen uit operationele activiteiten als een belangrijke maatstaf van de prestaties van een onderneming (zie bijvoorbeeld Nwaeze et al., 2005).

In dit artikel wordt ingegaan op de situatie waarin een onderneming te maken krijgt met veranderingen in solva- 
biliteit (leverage). Daarbij wordt onderzocht of er een verband bestaat tussen veranderingen in solvabiliteit en manipulatie door middel van werkelijke economische activiteiten met als mogelijk doel kasstromen uit operationele activiteiten te beïnvloeden.

Voordat ingegaan wordt op de voor dit artikel relevante literatuur en de hypothese in paragraaf 3 en 4 , wordt eerst aandacht besteed aan het begrip 'real earnings management' (paragraaf 2). De onderzoekmethoden komen aan de orde in paragraaf 5 en de resultaten worden gepresenteerd in paragraaf 6. Ten slotte worden conclusies en de beperkingen van het onderzoek gepresenteerd in paragraaf 7 en 8.

\section{Real earnings management}

Een aanzienlijk deel van de studies over resultaatsturing richt zich op manipulatie door middel van overlopende posten (accrual earnings management). Echter, accrual earnings management is niet het enige middel dat ondernemingen ter beschikking staat. Ook manipulatie door middel van economische activiteiten kan worden gebruikt om hetzelfde doel te bereiken. Bij zowel accrual earnings management als bij real earnings management blijft het management binnen de grenzen van de verslagleggingstandaarden. In tegenstelling tot accrual earnings management, kenmerkt real earnings management zich doordat de effecten zich niet alleen uitstrekken tot de winst (of het verlies) van de onderneming, maar dat real earnings management ook effect heeft op de kasstromen van de onderneming. Real earnings management beïnvloedt daarmee de werkelijke activiteiten en de daaruit voortvloeiende kasstromen van een onderneming. Graham et al. (2005) vinden het bewijs dat managers in bepaalde gevallen meer geneigd zijn economische activiteiten te manipuleren dan accrual earnings management toe te passen.

In de literatuur wordt het begrip 'real earnings management' op verschillende wijzen omschreven. Op basis van deze recente literatuur wordt real earnings management in dit artikel als volgt gedefinieerd:

'Real earnings management is a purposeful action by management of a company to alter reported earnings in a particular direction, which is achieved by changing the timing and/or structuring of an operation, investment and/or financial transaction with cash flow effects and has sub-optimal business consequences.'

Deze definitie is gebaseerd op de definitie van Zang (2007), waarbij is toegevoegd dat real earnings management gepaard gaat met 'cash flow effects'. Dit komt onder meer naar voren in studies van Dechow en Skinner (2006) en Zhang (2006). Uit de definitie valt op te maken dat er sprake moet zijn van een doelgerichte interventie door het management om gerapporteerde winsten te veranderen in een bepaalde richting. De doelgerichte interventie gaat gepaard met effecten op de gerapporteerde kasstromen.

In dit artikel wordt de nadruk gelegd op real earnings management. De reden hiervoor is tweeledig. Ten eerste, de negatieve economische gevolgen waarmee real earnings management gepaard gaat, maakt real earnings management een ernstige vorm van earnings management (Ewert en Wagenhofer, 2005; Chen et al., 2008). Roychowdhury (2006) en Burgstahler en Eames (2006) vinden systematische bewijzen dat managers ogenschijnlijk bereid zijn om potentiële langetermijnwinsten op te offeren om positieve winststijgingen op de korte termijn te behalen. Managers kunnen bijvoorbeeld tijdelijk hogere opbrengsten en kasstromen realiseren door hoge kortingen aan te bieden. Ten tweede, accrual earnings management heeft geen directe invloed op kasstromen, maar verandert slechts de timing van realisatie van ontvangsten en uitgaven, waarbij real earnings management daadwerkelijk gevolgen heeft voor kasstromen. Juist het feit dat bij manipulatie door middel van werkelijke transacties niet alleen de winst wordt beïnvloed maar ook de kasstromen uit operationele activiteiten, is een van de redenen dat managers deze vorm van manipulatie verkiezen (Zhang, 2006). Daarnaast kan meespelen dat real earnings management minder makkelijk is te identificeren in vergelijking met accrual earnings management (Roychowdhury, 2006).

\section{Toenemende aandacht voor kasstromen uit operationele activiteiten}

Beleggers zijn zich nu vaak terdege bewust van het begrip 'kwaliteit van de winst'. Als gevolg daarvan negeren sommige beleggers gerapporteerde winsten en gebruiken het operationele deel van het kasstroomoverzicht als een 'reality check' op de betrouwbaarheid van de gerapporteerde baten en lasten in de winst-enverliesrekening. Een veelgebezigde uitspraak is: 'Cash is king, profit is an opinion', maar zijn kasstromen wel zo vrij van beïnvloeding als algemeen wordt aangenomen?

Een aantal studies veronderstelt dat kasstromen vrij zijn van beïnvloeding (Givoly en Hayn, 2000; Barth, Cram en Nielson, 2001). In deze onderzoeken worden kasstromen als constante genomen om een voorspelling te doen betreffende de werkelijke prestaties van een onderneming. Echter, recente wetenschappelijke studies geven aan dat managers betrokken kunnen zijn bij en profiteren van beïnvloeding van kasstromen 
(Melendrez et al., 2005; Graham et al., 2005). Er zijn aanwijzingen dat managers daadwerkelijk acties ondernemen met het doel positieve of verbeterde kasstromen uit operationele activiteiten te rapporteren (Zhang, 2006). Er zijn zelfs resultaten uit recente onderzoeken die aantonen dat ondernemingen overgaan van accrual naar real earnings management (Cohen et al., 2008: Graham et al., 2005). Verder suggereert een recent onderzoek van Georgia Tech Financial Analysis Lab (Mulford, 2005) dat kasstromen, en in het bijzonder kasstromen uit operationele activiteiten, onderhevig zijn aan beïnvloeding.

Analoog aan winststuring zijn twee methoden te identificeren waarmee managers kasstromen uit operationele activiteiten kunnen beïnvloeden: voornamelijk door middel van werkelijke economische activiteiten, hetgeen analoog is aan real earnings management, en in mindere mate door middel van verslaggevingtechnieken, hetgeen analoog is aan het begrip accrual earings management. Enkele voorbeelden van activiteiten die kunnen duiden op de eerste vorm zijn het verkopen van debiteurenvorderingen, een vertraging in betaling van crediteuren en het verminderen van discretionaire uitgaven.

Met het belang van betrouwbare informatie voor beleggers betreffende deze kasstromen en de (negatieve) economische gevolgen die manipulaties van de werkelijke activiteiten zouden kunnen hebben (Gunny, 2006), ontstaat de vraag of ondernemingen in een bepaalde situatie, bijvoorbeeld ondernemingen met een relatieve hoge of toenemende schuldenlast, meer geneigd zijn om real earnings management toe te passen om daarmee kasstromen uit operationele activiteiten te verhogen.

\section{Solvabiliteit en relevantie voor real earnings management}

Zoals reeds opgemerkt in paragraaf 1 , leek de wereldwijde globalisatie die zich in de afgelopen decennia voltrok tot gevolg te hebben dat een onderneming alleen kon overleven door de krachten te bundelen door middel van fusies en overnames; deze werden in veel gevallen door middel van externe financiering bewerkstelligd. Ondernemingen met een hoge leverage lopen het risico van faillissement wanneer ze niet in staat zijn om aan rente- en aflossingsverplichtingen van hun externe financiering te voldoen. Tevens kunnen zij in de toekomst moeilijkheden ondervinden om nieuwe kredieten aan te trekken.

In navolging van Jelinek (2007) wordt onderzocht of er een correlatie bestaat tussen ondernemingen met een constant hoge leverage en ondernemingen met een toenemende leverage en hun gedrag op het gebied van earnings management. Eerdere publicaties suggereren dat onder- nemingen met een hoge leverage eerder geneigd zijn om earnings management toe te passen om daarmee te vermijden dat men niet aan de leningsvoorwaarden voldoet (Beatty en Weber, 2003; Dichev en Skinner, 2000; DeFond en Jiambalvo, 1994). Ondernemingen met een stijgende leverage worden daarentegen verondersteld minder mogelijkheid te hebben tot opportunistisch gedrag. Op basis van deze onderzoeken veronderstelt Jelinek dat ondernemingen met een hoge leverage zich mogelijk anders gedragen dan ondernemingen met een stijgende leverage op het gebied van earnings management. Echter, deze studies meten earnings management met behulp van accrual earnings management. Jelinek (2007) onderzoekt leverageveranderingen en concludeert dat toegenomen leverage geassocieerd wordt met verminderd accrual earnings management. Op basis hiervan stelt zij dat leverageveranderingen en leverageniveaus mogelijk een verschillende uitwerking hebben op earnings management. In mijn onderzoek wordt nagegaan of een dergelijk verband ook bestaat indien earnings management wordt bekeken vanuit het oogpunt van 'real earnings management'. De gedachte hierbij is dat ondernemingen die door een stijgende leverage minder mogelijkheid hebben tot opportunistisch gedrag op het gebied van accrual earnings management, mogelijk hun toevlucht zoeken in real earnings management.

Een relevant onderzoek over beïnvloeden van kasstromen uit operationele activiteiten werd uitgevoerd door Zhang (2006) en komt dicht bij de beschouwing van effect van leverage op real earnings management; hij onderzoekt de mogelijkheid of, onder andere, leningvoorwaarden een van de stimulansen vormen voor het management om kasstromen uit operationele activiteiten te beïnvloeden. Het resultaat van zijn onderzoek suggereert dat de coëfficiënt van de schuldconvenanten positief is, maar niet significant, omdat de methode om dergelijke stimulansen te onderkennen, te grof is. Resultaten van vorige studies laten geen significante relatie zien tussen schulden en real earnings management. Mogelijk omdat vorige studies gericht zijn op een constant niveau van leverage (hoog, laag) en niet op toenemende leverage. Er werd geen studie gevonden die de relatie onderzoekt met toenemende leverage en real earnings management.

Gebaseerd op de studie van Jelinek (2007), waarin onderscheid wordt gemaakt tussen ondernemingen waarvan de mate van leverage toeneemt en ondernemingen met een constant hoog niveau van leverage, is de hypothese als volgt geformuleerd:

H1: Ondernemingen die een toename van de mate van leverage vertonen, hebben een hoger niveau van real 
earnings management dan ondernemingen die een constant hoog niveau van leverage vertonen.

\section{Onderzoeksmethoden}

\subsection{Het model voor real earnings management}

In de literatuur worden twee methoden voor het meten van real earnings management gepresenteerd. De eerste methode is het meten van het totale niveau van real earnings management. Als een indicatie gebruikt men een abnormaal niveau van kasstromen uit operationele activiteiten (zie bijvoorbeeld Chen e. a., 2008; Roychowdhury, 2006). Voor het bepalen van het normale niveau van deze kasstromen gebruikt men een door Dechow et al. (1998) ontwikkeld model.

De tweede methode is ontwikkeld door Roychowdhury (2006). Om het effect van reële activiteiten beter waar te nemen, onderzoekt Roychowdhury het abnormale niveau van kasstromen uit operationele activiteiten, de abnormale discretionaire uitgaven en de abnormale productiekosten, en gebruikt als indicatie voor real earnings management de som van deze drie gestandaardiseerde real earnings management proxy's. Beïnvloeding middels overproductie leidt tot een verminderd niveau van operationele kasstromen; het verlagen van discretionaire uitgaven daarentegen leidt tot een verhoogd niveau van operationele kasstromen. Als gevolg van dit tegengestelde effect op kasstromen uit operationele activiteiten is ervoor gekozen om de eerste methode te hanteren.

Normale kasstromen uit operationele activiteiten:

Voor het bepalen van het normale niveau van de kasstromen uit operationele activiteiten voor elke onderneming en voor elk jaar, wordt het model gebruikt zoals ontwikkeld door Dechow et al. (1998) en zoals toegepast in het onderzoek van Roychowdhury (2006). Roychowdhury (2006) legt normale kasstromen uit operationele activiteiten uit als een lineaire functie van de omzet $\left(S_{i t}\right)$ en verandering in de omzet in de huidige periode $\left(\Delta S_{i t}\right)$. Alle variabelen in het model worden geschaald door te delen door totale activa $\left(\mathrm{TA}_{\mathrm{i}, \mathrm{t}-1}\right)$ te meten met een vertraging van een jaar. Het model ziet er als volgt uit:

(1) $\mathrm{CFO}_{\mathrm{it}} / \mathrm{TA}_{\mathrm{i}, \mathrm{t}-1}=\alpha_{\mathrm{ot}}+\alpha_{\mathrm{it}}\left[1 / \mathrm{TA}_{\mathrm{i}, \mathrm{t}-\mathrm{1}}\right]+\alpha_{2 \mathrm{t}}\left[\mathrm{S}_{\mathrm{it}} / \mathrm{TA}_{\mathrm{i}, \mathrm{t}-1}\right]+$ $\alpha_{3 \mathrm{t}}\left[\Delta S_{\mathrm{it}} / \mathrm{TA}_{\mathrm{i}, \mathrm{t}-1}\right]+\varepsilon_{\mathrm{it}}$

$\mathrm{CFO}_{\mathrm{it}}=$ kasstromen uit operationele activiteiten in de huidige periode

$\mathrm{TA}_{\mathrm{i}, \mathrm{t}-1}=$ totale activa op $\mathrm{t}-1$

$S_{\text {it }}=$ omzet in de huidige periode

$\Delta S_{i t}=$ verandering in omzet in de huidige periode
Abnormale kasstromen uit operationele activiteiten:

Daarna wordt voor elke onderneming en voor elk jaar het abnormale niveau van kasstromen uit operationele activiteiten bepaald (RE). Abnormale kasstromen uit operationele activiteiten zijn gelijk aan werkelijke kasstromen uit operationele activiteiten, verminderd met de berekende 'normale' kasstromen uit operationele activiteiten bij gebruikmaking van geschatte coëfficiënten uit de voorgaande vergelijking (1).

\subsection{Model voor het meten van leverageniveaus en gehanteerde controlevariabelen}

In de praktijk worden verschillende berekenmethoden van leverage gehanteerd, waarbij het voornaamste onderscheid is of meting van leverage geschiedt op basis van de boekwaarde of de marktwaarde van vreemd en eigen vermogen. Om te onderzoeken of een bepaalde methode van leveragemeting invloed heeft op real earnings management, is ervoor gekozen om drie meetmethoden te gebruiken.

Bij de eerste methode wordt leverage gemeten als de verhouding tussen de langlopende schulden en het totaal van de boekwaarde van het eigen vermogen en langlopende schulden. Deze methode verdient de voorkeur boven de meting van leverage als de verhouding tussen de langlopende schulden en de boekwaarde van het eigen vermogen. Een negatieve boekwaarde van het eigen vermogen zou anders resulteren in een laag leverageniveau (negatief), ondanks de absolute waarde van langlopende schulden (zie bijvoorbeeld Nwaeze et al., 2005 en Jelinek, 2007). De eerste methode voor het berekenen van leverage kan als volgt worden weergegeven:

(2) (Leverage) = langlopende schulden / (boekwaarde van het eigen vermogen + langlopende schulden).

Vervolgens wordt leverage gemeten op basis van de marktwaarde van het eigen vermogen. De formule is als volgt:

(3) (Leverage) = langlopende schulden tegen boekwaarde / marktwaarde van het eigen vermogen.

Ten slotte is de werkelijke boekwaarde van de langlopende schulden gebruikt als een maatstaf van leverage. Hierbij is de veronderstelling gemaakt dat een onderneming met een hoog absoluut bedrag aan schulden op lange termijn nauwlettend kan worden gevolgd door de uitgevende instelling van de schulden, ongeacht de relatieve waarde van langlopende schulden zoals gehanteerd in vergelijkingen 2 en 3 . De formule is als volgt: 
(4) (Leverage) $=$ langlopende schulden tegen boekwaarde

Grote ondernemingen worden meer gevolgd door analisten en verschillen in informatieomgeving van kleine ondernemingen. Om hiervoor te controleren, is een variabele (SIZE) in de regressie toegevoegd. In de regressie is daarnaast een variabele (CAPIN) opgenomen om te controleren voor kapitaalintensiteit. Zhang (2006) suggereert dat de kasstroominformatie relatief belangrijker is voor kapitaalintensieve ondernemingen dan voor niet-kapitaalintensieve ondernemingen.

\subsection{Model voor het meten van hypothesen}

Aangezien voor de berekening van leverage drie afzonderlijke modellen zijn gekozen, is de hypothese $\mathrm{H}_{1}$ verder verdeeld in drie subhypothesen. Voor de eerste methode waarbij de leverage is berekend op basis van boekwaarde (2), is de volgende hypothese ontwikkeld:

H1.A: Ondernemingen die een toename van de mate van leverage vertonen, hebben een hoger niveau van real earnings management dan ondernemingen die een constant hoog niveau van leverage vertonen, waarbij leverage is berekend op basis van boekwaarde.

Om de hypothese te toetsen, wordt de volgende regressie toegepast:

(5) $(\mathrm{RE})=\alpha_{0}+\alpha_{1}\left(\mathrm{LEV} \_\right.$INC $)+\alpha_{2}(\mathrm{SIZE})+\alpha_{3}(\mathrm{CAPIN})+\varepsilon_{i t}$

$\mathrm{RE}=$ real earnings management

LEV_INC = leverage (zie formule 2)

SIZE = omvang van de onderneming berekend als logaritme van marktwaarde van eigen vermogen, uitgedrukt als een afwijking van het jaargemiddelde

CAPIN = kapitaalintensiteit berekend als ratio van bruto materiële vaste activa gedeeld door omzet in het jaar $\mathrm{t}-1$

Voor de tweede methode voor de berekening van leverage op basis van marktwaarde (3) is de volgende hypothese ontwikkeld:

H1.B: Ondernemingen die een toename van de mate van leverage vertonen, hebben een hoger niveau van real earnings management dan ondernemingen die een constant hoog niveau van leverage vertonen, waarbij leverage is berekend op basis van marktwaarde.

Om de hypothese te toetsen, wordt de volgende regressie toegepast:

(6) $(\mathrm{RE})=\alpha_{0}+\alpha_{1}\left(\mathrm{LEV} \_\right.$INC $)+\alpha_{2}(\mathrm{SIZE})+\alpha_{3}(\mathrm{CAPIN})+\varepsilon_{\mathrm{it}}$
LEV_INC = leverage (zie formule 3)

Voor de derde methode waarin berekening van leverage is gebaseerd op de absolute waarde van langetermijnschulden (4), is de volgende hypothese ontwikkeld:

H1.C: Ondernemingen die een toename van de mate van leverage vertonen, hebben een hoger niveau van real earnings management dan ondernemingen die een constant hoog niveau van leverage vertonen, waarbij de absolute waarde van langetermijnschulden bij berekening van leverage wordt gehanteerd.

Om de hypothese te toetsen, wordt de volgende regressie toegepast:

(7) $(\mathrm{RE})=\alpha_{0}+\alpha_{1}\left(\mathrm{LTD} \_\mathrm{INC}\right)+\alpha_{2}(\mathrm{SIZE})+\alpha_{3}(\mathrm{CAPIN})+\varepsilon_{\mathrm{it}}$

LTD_INC $=$ leverage (zie formule 4)

\subsection{Periode en populatie}

In navolging van Roychowdhury (2006) wordt vereist dat kasstromen uit operationele activiteiten beschikbaar zijn in de database Compustat. Voor de identificatie van de periode wordt gebruikgemaakt van de resultaten van eerdere studies. Studies door Graham et al. (2005) en Cohen et al. (2008) tonen aan dat het niveau van real earnings management daalt voor de Sarbanes-Oxley Act (SOx) in 2002 en aanzienlijk toeneemt na het passeren van de wetgeving. Als gevolg daarvan wordt de populatie beperkt tot de post-2002-periode. De effecten van SOx worden eerder verwacht in financiële informatie van Amerikaanse ondernemingen. Buitenlandse ondernemingen die genoteerd zijn aan de Amerikaanse effectenbeurzen werden immers pas verplicht om te voldoen aan SOx vanaf 2005. Als gevolg daarvan verzamelt de studie gegevens voor Amerikaanse ondernemingen met beursnotering in Compustat. Financiële instellingen zijn uitgesloten van het onderzoek omdat het niveau van leverage van deze ondernemingen verschilt van andere ondernemingen als gevolg van de regelgeving voor financiële instellingen. Ondernemingen waarvan niet alle datapunten aanwezig zijn, zijn uitgesloten van het onderzoek. In totaal zijn 1287 ondernemingen opgenomen in het onderzoek (7722 waarnemingen) over de periode van 2001 tot 2006.

Voor het bepalen van de uiteindelijke populatie en indeling van ondernemingen wordt de selectiemethode gehanteerd zoals eerder gepresenteerd door Jelinek (2007). De totale populatie is verdeeld in de drie volgende populaties: tijdsperiode 1: jaar 2002-2004, tijdsperiode 2 : jaar 2003-2005 en tijdsperiode 3: jaar 2004-2006. Elk van de ondernemingen in deze populaties is vervolgens 
geclassificeerd in de volgende groepen: ondernemingen die een toename van de mate van leverage vertonen, ondernemingen die een constant hoog niveau van leverage vertonen en ondernemingen die van het onderzoek zijn uitgesloten. Een onderneming wordt geclassificeerd als een onderneming die een toename van de mate van leverage vertoont als het zich aan het begin van een periode in het eerste of tweede kwartiel bevindt en verplaatst is naar het derde of vierde kwartiel aan het einde van de periode. Een onderneming wordt geclassificeerd als een onderneming die een constant hoog niveau van leverage vertoont (controleonderneming) als een onderneming aan het begin en aan het eind van de periode in het derde of vierde kwartiel blijft. Alle ondernemingen zonder één van deze twee classificaties werden uitgesloten van het onderzoek. Verder werden observaties uitgesloten om de volgende redenen: 1) ondernemingen die werden geclassificeerd als ondernemingen met een toename van de mate van leverage in één (of meer) perioden en als controleondernemingen in een andere periode, en 2) ondernemingen die werden geclassificeerd als ondernemingen met een toename van de mate van leverage in meer dan één periode. Alleen het eerste datapunt voor een onderneming werd in het onderzoek meegenomen indien deze onderneming werd geclassificeerd als controleonderneming over meerdere perioden.

\section{Figuur 1 Bepaling van de ondernemingen met een toename van de mate van leverage en controleondernemingen}

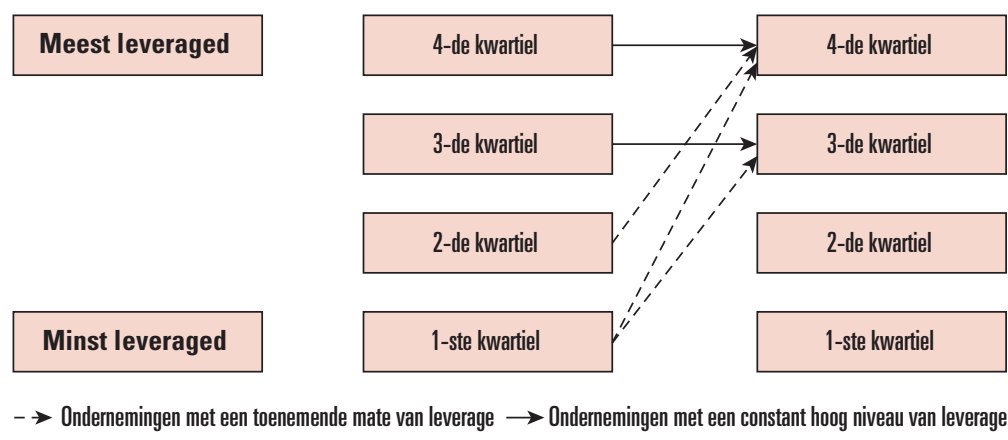

\section{Resultaten}

Allereerst zijn met behulp van regressievergelijking ( 1 ) de parameters geschat waarmee het normale niveau van kasstromen uit operationele activiteiten wordt benaderd. Daarna is leverage gemeten voor iedere onderneming in elk van de jaren. Tevens zijn de controlevariabelen (SIZE) en (CAPIN) berekend.

Vervolgens zijn de hypothesen getest met behulp van regressievergelijking (5), (6) en (7). De resultaten van deze regressievergelijkingen zijn weergegeven in tabel 1 , 2 en 3 .

Tabel 1 Hypothese H.1A

Leverage berekend op basis van boekwaarde van eigen vermogen

\begin{tabular}{|c|c|c|c|c|}
\hline & $\begin{array}{l}\text { Tijdsperiode } 1 \\
\text { 2002-2004 }\end{array}$ & $\begin{array}{l}\text { Tijdsperiode } 2 \\
\text { 2003-2005 }\end{array}$ & $\begin{array}{l}\text { Tijdsperiode } 3 \\
\text { 2004-2006 }\end{array}$ & Totaal \\
\hline Aantal bedrijven in onderzoek voor uitsluiting & 1.287 & 1.287 & 1.287 & - \\
\hline \multicolumn{5}{|l|}{ Aantal ondernemingen na uitsluiting: } \\
\hline Ondernemingen met toenemende leverage & 75 & 86 & 84 & 245 \\
\hline \multicolumn{5}{|l|}{ Ondernemingen met constant hoge leverage } \\
\hline Totaal aantal ondernemingen in finale populatie & 423 & 499 & 537 & 1.459 \\
\hline \multicolumn{5}{|l|}{ LEV_INC (Leverage toenemend) } \\
\hline Coëfficiënt (waarde) & 0.044 & 0.029 & -0.114 & -0.020 \\
\hline Significantie (waarde) & 0.194 & 0.437 & 0.006 & 0.386 \\
\hline \multicolumn{5}{|l|}{ SIZE } \\
\hline Coëfficiënt (waarde) & 0.024 & 0.018 & 0.032 & 0.026 \\
\hline Significantie (waarde) & 0.000 & 0.003 & 0.000 & 0.000 \\
\hline \multicolumn{5}{|l|}{ CAPIN } \\
\hline Coëfficiënt (waarde) & -0.041 & 0.000 & -0.002 & -0.002 \\
\hline Significantie (waarde) & 0.000 & 0.885 & 0.022 & 0.014 \\
\hline
\end{tabular}


Tabel 2 Hypothese H.1B

Leverage berekend op basis van marktwaarde van het eigen vermogen

\begin{tabular}{|c|c|c|c|c|}
\hline & $\begin{array}{l}\text { Tifdsperiode } 1 \\
\text { 2002-2004 }\end{array}$ & $\begin{array}{l}\text { Tifdsperiode } 2 \\
\text { 2003-2005 }\end{array}$ & $\begin{array}{l}\text { Tifdsperiode } 3 \\
\text { 2004-2006 }\end{array}$ & Totaal \\
\hline Aantal ondernemingen in onderzoek voor uitsluiting & 1.287 & 1.287 & 1.287 & - \\
\hline \multicolumn{5}{|l|}{ Aantal ondernemingen na uitsluiting: } \\
\hline Ondernemingen met toenemende leverage & 70 & 76 & 86 & 232 \\
\hline \multicolumn{5}{|l|}{ Ondernemingen met constant hoge leverage } \\
\hline (controle ondernemingen) & 252 & 304 & 348 & 904 \\
\hline Totaal aantal ondernemingen in finale populatie & 322 & 380 & 434 & 1.136 \\
\hline \multicolumn{5}{|l|}{ LEV_INC (Leverage toenemend) } \\
\hline Coëfficiënt (waarde) & -0.078 & 0.194 & 0.034 & 0.048 \\
\hline Significantie (waarde) & 0.222 & 0.040 & 0.097 & 0.193 \\
\hline \multicolumn{5}{|l|}{ SIZE } \\
\hline Coëfficiënt (waarde) & 0.029 & -0.004 & 0.033 & 0.020 \\
\hline Significantie (waarde) & 0.009 & 0.795 & 0.000 & 0.002 \\
\hline \multicolumn{5}{|l|}{ CAPIN } \\
\hline Coëfficiënt (waarde) & -0.005 & -0.006 & -0.001 & -0.001 \\
\hline Significantie (waarde) & 0.150 & 0.545 & 0.005 & 0.200 \\
\hline
\end{tabular}

De uitkomsten van de analyse voor hypothese H1.A tonen aan dat de coëfficiënt van leverage (LEV_INC) positief is, maar niet significant in de eerste twee regressies voor tijdsperiode 1 en 2 (p-waarde gelijk aan 0.194 en 0.437 ). In de regressie van tijdsperiode 3 wordt de coëfficiënt gemeld als negatief (-0.114) en significant (p-waarde 0.006). Echter, de verklarende kracht (adjusted R-kwadraat) is slechts gelijk aan 8 procent. De resultaten van de tijdsperiode 3 vereisen daardoor toekomstig onderzoek met behulp van een grotere populatie en een langere post-SOx-periode. Het uitvoeren van de regressie (5) voor de drie tijdsperioden samen toont geen significant resultaat.

De resultaten van regressieanalyse voor de hypothese H1.B zijn niet significant. De uitkomsten van tijdsperiode 2 duiden er wel op dat de coëfficiënt van leverage (LEV_INC) positief (0.194) en significant is op een 5-procentniveau ( $\mathrm{p}$ waarde 0.040), wat erop wijst dat ondernemingen waarvan de leverage toeneemt in tijdsperiode 2 meer geneigd zijn om kasstromen uit operationele activiteiten te manipuleren. De verklarende kracht (adjusted R-kwadraat) is gelijk aan 7 procent. Het uitvoeren van regressievergelijking (6) voor de drie tijdsperioden samen vertoont geen significant resultaat.

De resultaten van regressieanalyse Hi.C tonen aan dat de coëfficiënt van langetermijnschulden (LTD_INC) positief is en significant bij een 1-procentniveau in de drie tijdsperioden (tijdsperiode 1: 0.117, tijdsperiode 2: 0.142, tijdsperiode
3: 0.095), wat betekent dat de resultaten consistent zijn met H1.C. Met andere woorden, de resultaten van deze test suggereren dat managers van ondernemingen met toegenomen leverage meer geneigd zijn om kasstromen uit operationele activiteiten te beïnvloeden. Kasstromen uit operationele activiteiten in deze ondernemingen lijken meer gemanipuleerd te zijn dan in andere ondernemingen. Ook bij het uitvoeren van de regressie (7) voor de drie tijdsperioden samen is de coëfficiënt (LTD_INC) positief en significant bij een 1-procentniveau. Opmerkelijk is de relatie tussen de real earnings management proxy en de twee controlevariabelen (SIZE) en (CAPIN). De coëfficiënt op kapitaalintensiteit (CAPIN) is significant bij een 1-procentniveau en positief in alle regressies, hetgeen in overeenstemming is met het onderzoek van Zhang (2006). Daarin werd vastgesteld dat de kasstromen uit operationele activiteiten relatief belangrijker zijn voor kapitaalintensieve ondernemingen. In tegenstelling tot de resultaten van onderzoek van Zhang (2006), is de coëfficiënt van (SIZE) positief en significant in alle regressies. De verklarende kracht (adjusted R-kwadraat) van het laatste model is relatief hoog in vergelijking met de andere modellen en is gelijk aan 30 procent.

\section{Conclusie en discussie}

De resultaten van dit onderzoek wijzen erop dat real earnings management optreedt bij ondernemingen met toenemende leverage met als mogelijk doel om kasstromen uit operationele activiteiten te beïnvloeden. Deze resul- 
Tabel 3 Hypothese H.1C

De werkelijke boekwaarde van Long Term Debt wordt gebruikt

\begin{tabular}{|c|c|c|c|c|}
\hline & $\begin{array}{c}\text { Tijdsperiode } 1 \\
\text { 2002-2004 }\end{array}$ & $\begin{array}{c}\text { Tijdsperiode } 2 \\
\text { 2003-2005 }\end{array}$ & $\begin{array}{l}\text { Tfjdsperiode } 3 \\
2004-2006\end{array}$ & Totaal \\
\hline Aantal ondernemingen in onderzoek voor uitsluiting & 1.287 & 1.287 & 1.287 & - \\
\hline \multicolumn{5}{|l|}{ Aantal ondernemingen na uitsluiting: } \\
\hline Ondernemingen met toenemende leverage & 8 & 10 & 9 & 27 \\
\hline \multicolumn{4}{|l|}{ Ondernemingen met constant hoge leverage (controle } & 351 \\
\hline Totaal aantal ondernemingen in finale populatie & 115 & 130 & 133 & 378 \\
\hline \multicolumn{5}{|l|}{ LTD_INC (Toename langetermijnschulden) } \\
\hline Coëfficiënt (waarde) & 0.117 & 0.142 & 0.095 & 0.113 \\
\hline Significantie (waarde) & 0.000 & 0.002 & 0.001 & 0.000 \\
\hline \multicolumn{5}{|l|}{ SIZE } \\
\hline Coëfficiënt (waarde) & 0.035 & 0.039 & 0.030 & 0.035 \\
\hline Significantie (waarde) & 0.000 & 0.000 & 0.000 & 0.000 \\
\hline \multicolumn{5}{|l|}{ CAPIN } \\
\hline Coëfficiënt (waarde) & 0.087 & 0.146 & 0.091 & 0.107 \\
\hline Significantie (waarde) & 0.000 & 0.000 & 0.000 & 0.000 \\
\hline
\end{tabular}

taten worden bereikt indien men de absolute waarde van langlopende schulden hanteert bij de berekening van leverage. Met andere woorden, de resultaten suggereren dat ondernemingen met toenemende langetermijnschulden meer geneigd lijken te zijn om kasstromen uit operationele activiteiten te manipuleren.

De resultaten dragen het volgende bij aan de bestaande literatuur. Ten eerste, deze studie is de eerste real earnings management-studie die gebaseerd is op het model van Jelinek (2007) en meet het effect van leverageniveau en leverageveranderingen op abnormale kasstromen uit operationele activiteiten. Ten tweede, het resultaat is belangrijk in het licht van eerdere recente literatuur over leverage en real earnings management, waarbij onderzoekers geen significante associatie vonden tussen leverage en real earnings management als motief voor managers om kasstromen uit operationele activiteiten te beïnvloeden (Roychowdhury, 2006, p. 35; Zhang, 2006, p. 26). Dit is mede veroorzaakt doordat de voorgenoemde onderzoekers zich richten op constante leverage (hoog, laag of geschaald) en niet op leveragetoename. Het is echter belangrijk om bepaalde beperkingen van dit onderzoek in gedachten te houden, die hierna in paragraaf 8 worden besproken.

\section{Beperkingen en suggesties voor verder onderzoek}

In dit onderzoek zijn aannames gemaakt en zijn bepaalde beperkingen aangebracht. Toekomstig onderzoek kan worden uitgebreid of worden verbeterd op een aantal gebieden.

Ten tijde van dit onderzoek waren data voor niet-Amerikaanse ondernemingen die voor een periode van vier jaar voldeden aan de vereisten van SOx beperkt beschikbaar. Als gevolg daarvan zijn alleen Amerikaanse ondernemingen betrokken in het onderzoek.

Bij berekening van leverage op marktwaarde is ervoor gekozen om de aandelenwaarde te meten op marktwaarde en vreemd vermogen op boekwaarde. Een nieuwe hypothese kan ontwikkeld worden om vreemd vermogen op actuele waarde te waarderen. Deze meting is mogelijk subjectief, aangezien de meting van marktwaarde van vreemd vermogen veelal is gebaseerd op credit ratings.

Ook zouden andere factoren een rol kunnen spelen die in dit onderzoek niet aan bod gekomen zijn. Een van deze factoren is de gehanteerde methode om abnormale kasstromen uit operationele activiteiten te meten. Deze wordt namelijk gemeten op basis van enkele parameters uit de voorgaande periode (totale activa). Hierdoor worden stijgende bedrijfsactiviteiten in het huidige jaar, bijvoorbeeld door overnames, die stijgende kasstromen uit operationele activiteiten zouden rechtvaardigen, niet zonder meer ondervangen en kunnen kasstromen ten onrechte als abnormaal worden aangewezen. Het 
ontwikkelen van een meer gedetailleerd model voor het bepalen van verwachte kasstromen zou dit kunnen ondervangen. Tot slot maakt de bepaling van abnormale kasstromen mogelijk onvoldoende onderscheid tussen gerechtvaardige abnormale kasstromen, bijvoorbeeld als gevolg van economische en strategische beslissingen, en ongerechtvaardigde kasstromen met suboptimale consequenties voor de ondernemingen. Ook hier zou het ontwikkelen van een meer gedetailleerd model voor het bepalen van verwachte kasstromen dit kunnen ondervangen.

I. Zagers-Mamedova M.Sc. is financieel directeur bij Nordmet

SA te Geneva (Zwitserland). Dit artikel is afgeleid van de

masterscriptie van de auteur geschreven aan de Faculteit

Economische Wetenschappen (FEW) van de Erasmus

Universiteit Rotterdam.

\section{Literatuur}

Barth, M.E., D. Cram en K. Nelson (2001), Accruals and the prediction of future cash flows, The Accounting Review, vol. 76. pp. 27-58. - Beatty, A. en J. Weber (2003), The effects of debt contracting on voluntary accounting method changes, The Accounting Review, vol. 76, pp. 27-59.

- Chen, Z., L.L. Rees en S. Sivaramakrishnan (2008), On the use of accounting vs. real earnings management to meet earnings expectations - A market analysis, Working Paper, University of Houston, Texas A\&M University; available at SSRN: http://ssrn.com/ abstract=1070122

- Cohen, D., A. Dey en T. Lys (2008), Real and accrual based earnings management in the preand post-Sarbanes Oxley periods, The Accounting Review, vol. 83, no 3, pp. 757-787. - Dechow P. M., S. P. Kothari en L. R. Watts (1998), The relation between earnings and cash flows, Journal of Accounting and Economics, vol. 25, pp. 133-168.

Dechow, P.M. en D.J. Skinner (2000), Earnings management: reconciling the views of accounting academics, practitioners, and regulators, Accounting Horizons, vol. 14, pp. 235-250.

- DeFond, M.L. en J. Jiambalvo (1994), Debt covenant violation and manipulation of accruals,
Journal of Accounting and Economics, vol. 17, pp. 145-176.

- Ewert, R. en Wagenhofer (2005), Economic effects of tightening accounting standards to restrict earnings management, The Accounting Review, vol. 80, pp. 1101-1124.

-Givoly, D. en C. Hayn (2000), The changing time series properties of earnings, cash flow and accruals: Has financial reporting become more conservative? Journal of Accounting and Economics, vol. 29, pp. 287-320

- Graham, J.R., C.R. Harvey en S. Rajgopal (2005), The economic implications of corporate financial reporting, Journal of Accounting and

Economics, vol. 40, pp. 3-73.

-Gunny, K. (2005), What are the consequences of real earnings management? Working Paper, University of Colorado at Boulder.

- Healy, P.M. en J.M. Wahlen (1999), A review of the earnings management literature and its implications for standard setting, Accounting Horizons, vol. 13, pp. 365-383.

- Jelinek, K. (2007), The effect of leverage increases on earnings management, Journal of Business and Economic Studies, vol. 13, pp. 24-46.

- Melendrez, K., W. Schwartz en M. Trombley (2005), How does the market value accrual and cash flow surprises? Working Paper, Louisiana State University and University of Arizona; available at SSRN: http://ssrn.com/ abstract $=676651$.

- Mulford, C., Comiskey, E. (2005), Creative cash flow reporting: Uncovering sustainable financial performance, Hoboken, NJ: John Wiley \& Sons Inc.

- Nwaeze, E.T., S.S.M. Yang en Q.J. Yin (2005), Accounting information and CEO compensation: The role of cash flow from operations in the presence of earnings, Contemporary Accounting Research, vol. 23, no. 1, pp. 227-265.

Roychowdhury, S. (2006), Earnings management through real activities manipulation, Journal of Accounting and Economics, vol. 42, pp. 335-370.

- Zang, A.Y. (2007), Evidence on the tradeoff between real manipulation and accrual manipulation, Working Paper, Simon School University of Rochester; available at SSRN: http://ssrn.com/abstract=961293

- Zhang, R. (2006), Cash flow management, incentives, and market pricing, Working Paper Guanghua School of Management, available at SSRN: http://ssrn.com/abstract=817324. 